\title{
smwrBase-An R Package for Managing Hydrologic Data, Version 1.1.1
}

Open-File Report 2015-1202 



\section{smwrBase-An R Package for Managing Hydrologic Data, Version 1.1.1}

By David L. Lorenz

Open-File Report 2015-1202

U.S. Department of the Interior U.S. Geological Survey 


\title{
U.S. Department of the Interior SALLY JEWELL, Secretary
}

\section{U.S. Geological Survey \\ Suzette M. Kimball, Acting Director}

\author{
U.S. Geological Survey, Reston, Virginia: 2015
}

For more information on the USGS - the Federal source for science about the Earth, its natural and living resources, natural hazards, and the environment—visit http://www.usgs.gov or call 1-888-ASK-USGS.

For an overview of USGS information products, including maps, imagery, and publications, visit http://www.usgs.gov/pubprod/.

Any use of trade, firm, or product names is for descriptive purposes only and does not imply endorsement by the U.S. Government.

Although this information product, for the most part, is in the public domain, it also may contain copyrighted materials as noted in the text. Permission to reproduce copyrighted items must be secured from the copyright owner.

Suggested citation:

Lorenz, D.L., 2015, smwrBase-An R package for managing hydrologic data, version 1.1.1: U.S. Geological Survey Open-File Report 2015-1202, 7 p., http://dx.doi.org/10.3133/ofr20151202.

ISSN 2331-1258 (online) 


\section{Contents}

Abstract
Introduction
Description of smwrBase
Summary
Disclaimer
Acknowledgments
References Cited
Appendixes
Appendix 1. R Documentation 2. Regression Strategies Vignette

\section{Tables}

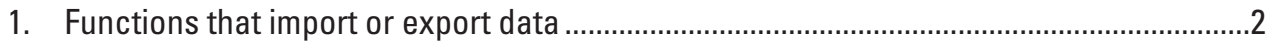

2. Functions that apply a transformation to one or more vectors. These functions always produce a single vector that is equal in length to the input .................................

3. Functions that manipulate data other than producing a single vector that is equal in length to the input. 



\title{
smwrBase-An R Package for Managing Hydrologic Data, Version 1.1.1
}

\author{
By David L. Lorenz
}

\begin{abstract}
This report describes an R package called smwrBase, which consists of a collection of functions to import, transform, manipulate, and manage hydrologic data within the $\mathrm{R}$ statistical environment. Functions in the package allow users to import surface-water and groundwater data from the U.S. Geological Survey's National Water Information System database and other sources. Additional functions are provided to transform, manipulate, and manage hydrologic data in ways necessary for analyzing the data.
\end{abstract}

\section{Introduction}

The U.S. Geological Survey (USGS) seeks to make hydrologic data highly available and easy to acquire to the many user communities. The R package smwrBase was developed to meet those goals for the $\mathrm{R}$ user communities that need hydrologic data. This report presents a collection of functions for hydrologic data - streamflow, groundwater elevations, and discrete water-quality concentrations - that can be used to import, transform, manipulate, and manage those data. These functions are provided as an $\mathrm{R}$ package called smwrBase. The functions in the package have been developed by the USGS to import data from the USGS's National Water Information System (NWIS) database and other sources, and transform, manipulate, and manage hydrologic data in ways necessary for analyzing the data. This $\mathrm{R}$ package provides a convenient mechanism for distributing the tools to users of $\mathrm{R}$ within the USGS and other communities.

\section{Description of smwrBase}

The R package smwrBase consists of a collection of functions to import, transform, manipulate, and manage hydrologic data within the $\mathrm{R}$ statistical environment.
Functions in the package allow users to import surface-water and groundwater data from the USGS's NWIS database and other sources. Additional functions are provided to transform, manipulate, and manage hydrologic data in ways necessary for analyzing the data. Documentation for the functions is provided in appendix 1 .

The functions in smwrBase are provided as a package in R (http://www.r-project.org/), an open source language and environment for statistical computing and graphics that runs on a variety of operating systems including UNIX $^{\circledR}$, Linux ${ }^{\circledR}$, Windows ${ }^{\circledR}$, and $\mathrm{Mac}_{\mathrm{OS}}{ }^{\circledR}$. The R statistical environment can be extended for additional functionality using packages. Additional information on the installation and administration of $\mathrm{R}$ and packages that extend $\mathrm{R}$ is available in the manual "R Installation and Administration" (R Development Core Team, 2014).

Many of the functions in the smwrBase package, version 1.1.1, have been ported from the USGS library for S+ (Lorenz and others, 2011). Other functions have been developed and used within the USGS since the publication of Lorenz and others (2011). All of the functions are in the public domain (see the "Disclaimer" section).

The suggested citation for data from the smwrBase package can be acquired by using the citation function in $\mathrm{R}$. The call is citation (package="smwrBase").

The import and export functions, and other functions that support or facilitate the import and export of data, are listed in table 1. Data transformation functions are listed in table 2. In general, these data transformation functions accept a vector and other arguments used by the various transformations and return a vector of the transformed values. Random number generating functions for the Pearson type III and log-Pearson type III distributions are also listed in table 2. Functions that manipulate data, such as merging or restructuring datasets, decomposing a vector into components, providing type checking functions, and performing other miscellaneous functions, are listed in table 3.

In addition to these named functions, the smwrBase package has support functions for objects of class "timeDay," output from the function as.timeDay. These include 
Table 1. Functions that import or export data.

[ASCII, American Standard Code for Information Interchange]

\begin{tabular}{|c|c|}
\hline $\begin{array}{l}\text { Function } \\
\text { name }\end{array}$ & Description \\
\hline exportCSV & $\begin{array}{l}\text { Export a data frame to a comma-separated values } \\
\text { file. }\end{array}$ \\
\hline exportRDB & Export data to an ASCII relational-database file. \\
\hline importCSV & $\begin{array}{l}\text { Import a data frame from a comma-separated } \\
\text { values file. }\end{array}$ \\
\hline importRDB & $\begin{array}{l}\text { Import a data frame from an ASCII relational- } \\
\text { database file. }\end{array}$ \\
\hline makeMeta & $\begin{array}{l}\text { Create a template meta file for a comma-separated } \\
\text { values file. }\end{array}$ \\
\hline readList & Import data arranged on lines into a list. \\
\hline setFileType & Support function to manage file suffixes. \\
\hline
\end{tabular}

method functions for addition (to objects of class "Date" and "POSIXt"), as.character, as.data.frame, format, is.na, length, print, and show.

The smwrBase package has detailed help files for each function that may be accessed in the same manner as help for other R functions. Help features within R are further described in the manual "An Introduction to R" (Venables and others, 2014). 
Table 2. Functions that apply a transformation to one or more vectors. These functions always produce a single vector that is equal in length to the input.

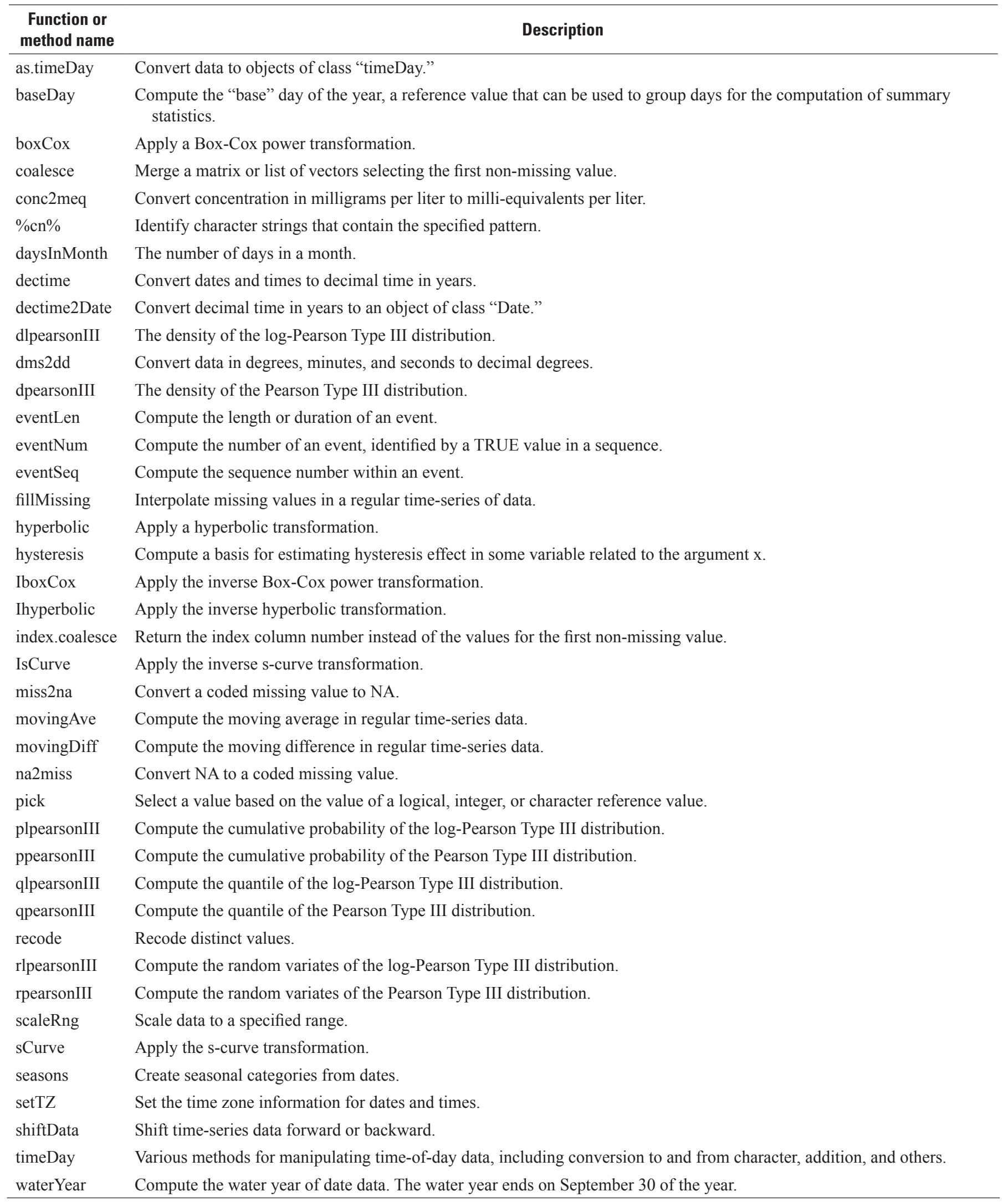


Table 3. Functions that manipulate data other than producing a single vector that is equal in length to the input..

\begin{tabular}{|c|c|}
\hline Function name & Description \\
\hline anomalies & Break down time-series data into long- and short-term deviations (anomalies) and the high-frequency variation. \\
\hline conc.meq & Support function for conc $2 \mathrm{meq}$ - produces a data frame read by conc $2 \mathrm{meq}$. \\
\hline fourier & Compute the Fourier series decomposition from date data. \\
\hline group2row & Unstack data oriented in columns to rows of data. \\
\hline isGroupLike & Determine whether the data can be treated like grouping data. \\
\hline isNumberLike & Determine whether the data can be treated as numeric data. \\
\hline mergeNearest & Merge two datasets by the nearest date and time. \\
\hline mergeQ & Merge flow data with water-quality data. \\
\hline regularSeries & Put data collected at arbitrary times into a regular time series. \\
\hline screenData & Screen data for missing values or gaps. \\
\hline seqCollapse & Collapse a sequence of integers to a compact character string. \\
\hline sumComposition & Compute the percentages of data within a matrix. \\
\hline untable & Expand a 2-dimensional table into the raw values. \\
\hline whichRowCol & Identify the row and column indexes for TRUE values in a logical matrix. \\
\hline
\end{tabular}

\section{Summary}

This report presents a collection of functions for hydrologic data - streamflow, groundwater elevations, and discrete water-quality concentrations - that can be used to import, transform, manipulate, and manage those data. These tools are provided as functions in an R package called smwrBase. The tools in the package have been developed by the U.S. Geological Survey to import data from the U.S. Geological Survey's National Water Information System (NWIS) database and other sources, and transform, manipulate, and manage hydrologic data in ways necessary for analyzing the data. This $\mathrm{R}$ package provides a convenient mechanism for distributing the tools to users of R within the U.S. Geological Survey and other communities.

\section{Disclaimer}

This package was written by U.S. Federal Government employees in the course of their employment and is therefore in the public domain, which means it is not copyrighted and use is unlimited; however, some of the functions depend on other R packages, which, although free and open source, have more restrictive licensing. Those packages are digest and lubridate (GNU [Gnu's Not Unix] GPL [General Public License], memoise [Massachusetts Institute of Technology, MIT], XML [Berkeley Software Distribution, BSD]. The R program itself is released under the free software license GNU GPL, either version 2, June 1991, or version 3, June 2007. Additional information on licensing is available at $\mathrm{http}: / / \mathrm{www} . \mathrm{r}-$ project. org/Licenses/ and http://www.gnu.org/licenses/license-list. $\mathrm{html}$ HSoftwareLicenses.

Although this software package has been used by the U.S. Geological Survey (USGS), no warranty, expressed or implied, is made by the USGS or the U.S. Government as to the accuracy and functioning of the program and related program material nor shall the fact of distribution constitute any such warranty, and no responsibility is assumed by the USGS in connection therewith. This software and related material (functions and documentation) are made available by the USGS to be used in the public interest and the advancement of science. Users may, without any fee or cost, use, copy, modify, or distribute this software, and any derivative works thereof, and its supporting documentation, subject to the USGS Software User's Rights Notice, http://water.usgs.gov/software/ help/notice/. 


\section{Acknowledgments}

The author thanks the time and effort of the U.S. Geological Survey personnel who reviewed this package and contributed suggestions to improve the package. The reviewers were Virginia McGuire, Nebraska Water Science Center; and Mark Brigham, Minnesota Water Science Center.

\section{References Cited}

Lorenz, D.L., Ahearn, E.A., Carter, J.M., Cohn, T.A., Danchuk, W.J., Frey, J.W., Helsel, D.R., Lee, K.E., Leeth, D.C., Martin, J.D., McGuire, V.L., Neitzert, K.M., Robertson, D.M., Slack, J.R., Starn, J., Vecchia, A.V., Wilkison, D.H., and Williamson, J.E., 2011, USGS library for S-PLUS for Windows-Release 4.0: U.S. Geological Survey Open-File Report 2011-1130, accessed December 5, 2014, at http:// pubs.er.usgs.gov/publication/ofr20111130.

R Development Core Team, 2014, R installation and administration, version 3.1.2 (2014-10-31): accessed February 11, 2015, at http://streaming.stat.iastate.edu/CRAN/doc/ manuals/R-admin.pdf.

Venables, W.N., Smith, D.M., and the R Development Core Team, 2014, An introduction to R, version 3.1.2 (2014-1031): accessed February 11, 2015, at http://cran.r-project.org/ doc/manuals/R-intro.pdf. 



\section{Appendixes}

\section{Appendix 1. R Documentation}

The $\mathrm{R}$ documentation is a pdf file that can be accessed at http://pubs.usgs.gov/ofr/2015/1202/downloads/appendix1.pdf.

\section{Appendix 2. Regression Strategies Vignette}

Vignettes are the established R community method for providing examples of how to use the package. The vignette for regression strategies is a pdf file that can be accessed at http://pubs.usgs.gov/ofr/2015/1202/downloads/appendix2.pdf.

\section{Appendix 3. Summary Statistics Vignette}

Vignettes are the established R community method for providing examples of how to use the package. The vignette for summary statistics is a pdf file that can be accessed at http://pubs.usgs.gov/ofr/2015/1202/downloads/appendix3.pdf. 
Publishing support provided by:

Rolla Publishing Service Center

For more information concerning this publication, contact: Director, USGS Minnesota Water Science Center

2280 Woodale Drive

Mounds View, Minnesota 55112

(763) 783-3100

Or visit the Minnesota Water Science Center Web site at: http://mn.water.usgs.gov/ 



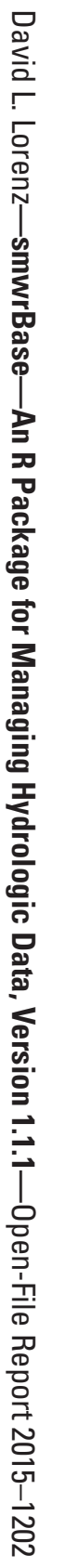

